\title{
Film education in Europe: National cultures or European identity?
}

\author{
Mark Reid* - British Film Institute, UK
}

\begin{abstract}
This paper considers the extent to which European countries have distinctive models and approaches to film education, and the extent to which a supranational model of European film education might exist in competition with those national models. It considers where film education is positioned in relation to other subject fields and disciplines (literacy and media literacy); the role of the European Commission in promoting both European and national approaches to film education; and the potential of transnational film education programmes to move between national and supranational film education cultures. It draws on data collected for Screening Literacy, a survey of film education funded by the European MEDIA programme that was carried out in 2012.
\end{abstract}

Keywords: film education; film literacy; film education in Europe; cinema education

\section{Introduction}

An initial look at Europe might support the idea that what could be characterized as different national film cultures exist. France, for example, proudly celebrates cinema as the seventh art, and awards its favoured directors the same 'artist' status as painters and writers. French film culture is preserved through decisive state intervention: a ban on screening film trailers and advertisements and 'film-free' Friday evenings on public service television, to encourage people to go to the cinema. On even a cursory consideration, the high valuation of film as art is in turn reflected in the character of French film education, which has an aesthetic focus on art cinema (though with some room for popular cinema), a sense of the global and historical canvas of film, proudly celebrates 'the cinema' as the pinnacle of film culture, and is dirigiste and elitist in its canonizing of certain film-makers and films.

A different picture obtains in the UK, where film culture has historically both flourished and laboured under the influence of Hollywood, principally because of a shared language that allows Hollywood cinema to travel without the impediments of subtitles or the cost (and awkwardness) of dubbing. Some commentators have viewed the shared language as a curse, with Nick Roddick (1985: 5) pointing out that 'if the USA spoke Spanish, the UK would have a film industry', while others can point to close and reciprocal artistic and industrial bonds and influences, such as the transatlantic career of Alfred Hitchcock. One can also point to a strong Hollywood influence on film education in the UK, with its plethora of film competitions, mock Oscar and BAFTA competitions, red carpet events, and the close involvement of famous film actors and professionals.

A third picture is offered by a country such as Lithuania, whose film culture evolved alongside political and cultural changes in the Soviet and post-Soviet orbit across the 
twentieth century, and to a great extent mirrored this evolution. As a satellite region of the USSR that has subsequently become a small independent nation, Lithuania had the capacity for only a small indigenous feature-film industry. The documentary form had a greater impact, made as subversive culture before 1989 and as increasingly confident national expression afterwards. (For example, see Meno Avilys, 2015). After the collapse of the Soviet Union in 1989, Lithuanian culture began a process of readjusting to its new political reality. Its emerging film education infrastructure was driven by a group of enthusiastic young people behind the Skalvija Cinema Centre, who had studied or interned abroad, and non-governmental organizations (NGOs) such as Meno Avilys. A complex relationship with Russia, and Russian film and media, continues as a strand in Lithuanian film education: important Lithuanian films are held only in the Russian state archives, and progress in reclaiming and restoring them is slow. Powerful Russian media interests continue to target the Baltic states, leading to calls for a strong media literacy to counter their messages and values.

All three of these nations - France, the UK and Lithuania - are members (at the time of writing, 2018) of the European Union (EU), an economic and political association of 28 nations, with more affiliated through the European Economic Area (EEA), committed to economic, social and cultural collaboration. (For a full list, see Government Digital Service, n.d.). The EU provides a political superstructure fostering collaborative approaches to culture and trade, while simultaneously allowing for national self-determination. The EU has an explicit role in helping define what it is to be 'European', especially in the arts and culture, including media and film. A central question for this article, therefore, is how 'European-ness' is manifest in the film education cultures, systems and practices of individual European countries, and how notions of 'Europe' play out with, and against, national cultures, identities and structures of film education.

\section{The European Union and film education policy}

The European Commission, the civil service of the European Union, takes a central role in the creation and circulation of European identity, in a range of directorates general that cover every aspect of trade and culture from agriculture to translation. (For a full list of EU directorates general, see European Commission, n.d.). Since 1991, the EU has taken an active interest in promoting media and film under the twin drivers of industrial and cultural interests. Jacques Delors (Commission President from 1985 to 1995) gave the audiovisual industries special status when he stated that 'the audio-visual is not a merchandise like others, so it requires a specific regulation' (quoted in Messerlin et al., 2004: 27). This 'special status' was expressed in a series of MEDIA Programmes running from 1991. Since the MEDIA programme of 2007-14, when the relevant directorate general was renamed Education and Culture, the MEDIA Unit has supported 'media literacy' within a broader support for media industries, especially film and television. The Commission expresses its focus thus:

Media literacy is vital for economic growth and job creation. Digital technologies are a key driver of competitiveness and innovation in the media, information, and communication technology sectors (European Commission, 2018a).

Of the $€ 755$ million allocated by the MEDIA programme between 2007 and 2014, between 1 and 2 per cent was spent on education. The rationale behind support for media literacy has always explicitly been to support media industries, and to protect 
and nurture European audiovisual culture as an expression of European heritage. In fact, for much of the time in EU MEDIA policy, 'media' effectively served as a synonym for 'film': the money was to 'support the development and distribution of thousands of films, as well as training activities, festivals, and promotional projects throughout the continent ... to strengthen the audio-visual sector; increase the circulation of European audio-visual works; and to strengthen competitiveness' (European Commission, 2018b).

In 2014, the European Commission's arts, cultural and MEDIA programmes merged to become Creative Europe, another seven-year fund, this time amounting to some €1.46 billion. The 'media literacy' component became explicitly a focus on 'film literacy':

activities aimed at promoting film literacy and at increasing audiences' knowledge of, and interest in, European audiovisual works, including the audiovisual and cinematographic heritage, in particular among young audiences (EACEA, 2016).

Like the MEDIA programme before it, Creative Europe remains explicitly transnational in emphasis: the European Commission outlaws national interventions in culture, education, business or industry (so called 'state aid'), while at the same time supporting European heritage and culture (under the so-called 'cultural exception'). The European Commission also cannot intervene in national or regional education jurisdictions. Europe is therefore saddled with a contradiction: comprising more than thirty nations and four hundred official languages, and many more ethnic groups and languages that it seeks to enable, develop and sustain under the banner of a single 'European' flag, which many argue has no real ontological status or small-p political legitimacy.

The European Commission seeks to support film literacy principally through funding media and film education projects, which tend to be between 12 and 18 months in length, with a minimum of three different national partners and three project languages, typically costing between $€ 60,000$ and $€ 150,000$. Examples include CinEd, a project to create a catalogue of European feature films for children, along with screening notes and teaching resources; $A B C i n e m a$, an exchange programme for young people learning how to programme 'cultural cinema'; and Inside Cinema, a website hosting archive materials that 'open up' our understanding of classic European films. (For examples of projects, see EACEA, 2014.) While these funded projects are explicitly transnational through the involvement of multiple partners, whether they express a common 'Europeanness' is a different question.

Without being formally adopted as European instruments, two projects over the last ten years have attempted to set out some common European standards and principles in media and film education - and received some European endorsement in the form of funding. The first, the European Charter for Media Literacy (Euro Media Literacy, 2009) set out a definition of media literacy, and invited individuals, organizations, schools and others to endorse it in the form of a signature as supporter, sponsor or provider. To date, the charter has many thousands of signatories and registrations, and might be considered an example of the power of grass-roots, as opposed to top-down, transnational organizing. The second, the European Framework for Film Education (BFI, 2015), was created by a group of 25 film educators from European countries, attempting to codify some of the varying, plural approaches to teaching film across Europe. The framework's focus was on identifying a common set of 'learning outcomes' - that is, experiences, skills and knowledge that it could confidently be asserted are fostered as a result of specific types of activity. There are other examples 
of transnational, European, film education projects that are not supported by European Union funding, one of which will be considered towards the end of this article.

\section{Distinctions and definitions: Media, film and literacy}

One approach to establishing a common European identity for film education is to attempt to set out a set of shared definitions for film and media literacy. Attempts to do so, however, have not proven straightforward. For some time the word 'media' has served as a catch-all for cultural activity that does not fall under either traditional art forms or long-established communication practice. The word 'media' can include anything digital or hosted on the internet, advertising, radio, television and film. Film itself can be any moving image product found on a range of platforms from cinemas to YouTube files browsed on a mobile phone. These categories are slippery and overlapping: they mix symbolic meaning-making systems (film as a language and art form), with medium of communication (mobile devices, binary code, radio broadcast signals), with industrial sectors (advertising), while at the same time leaving out traditional meaning-making systems (speech, written language, music), even though these systems are completely integrated into contemporary digital media (one cannot use Twitter without being able to write, for example). When it comes to defining 'media literacy', therefore, these confusions are transferred into classrooms, cinemas, and education and cultural policy.

The European Commission has attempted to achieve some degree of commonality over film and media literacy by publishing its own definition:

Media literacy refers to all the technical, cognitive, social, civic and creative capacities that allow us to access and have a critical understanding of and interact with media. These capacities allow us to exercise critical thinking, while participating in the economic, social and cultural aspects of society and playing an active role in the democratic process (European Commission, 2018a).

Within the media definition, the commission then conceives of film literacy as being:

The level of understanding of a film; the ability to be conscious and curious in the choice of films; the competence to critically watch a film and to analyse its content, cinematography and technical aspects; and the ability to manipulate its language and technical resources in creative moving image production (School Education Gateway, 2017).

Over the last 15 years, participants active in the field have persistently argued that a full definition of media or film literacy should be about making as well as consuming media, (Buckingham, 2003; Burn and Durran, 2007). In 2013, following a recommendation in the research survey Screening Literacy (BFI, 2013), the European Commission's definition of film literacy was amended to include 'making', as well as 'watching'. Up until that point, media and film education were understood as contributing only to the development of adventurous and discerning audiences, judicious in their choices of film content, rather than active users and makers of media or film.

Furthermore, the overall notion of 'literacy' is itself not so straightforward, and its use as a metaphor for understanding film does not travel comfortably across national boundaries in Europe. A 'literacy' is properly understood as the outcome of a learning process: in learning to read and write, one becomes literate. Narrower definitions of literacy tie the process of becoming literate to the acquisition of written language, 
which still remains the most socially powerful and sanctioned meaning-making system in most cultures.

Certain writers and educators in Europe are explicitly resistant to the 'literacy' model of film, among them the French theorist and critic Alain Bergala. Bergala argues that to conceive of film as 'language' or 'readable object' reduces and 'tames' the object of the film, negating its 'radical impurity'. Bergala argues film is not like written language, a symbolic adaptation of the world into another semiotic system, but rather (quoting Pasolini) a 'language written from reality ... written in the total and natural language that is action in reality ... representing reality by way of reality' (Bergala, 2016: 25-6).

A different conception of literacy can be derived from the work of the new literacy studies (for example, Cope and Kalantzis, 2000), in which literacy is defined as being able to participate in society and culture fully. A 'participatory' definition decouples literacy from single specific symbolic systems such as writing, and expresses it as a socially empowering process. Being literate in this sense thus requires different experiences and skills in the twenty-first century than it did in the sixteenth or nineteenth centuries. Today, with YouTube, on-demand film and television, and tiny GIFs and Vines (Twitter video clips) on social media, the moving image is ubiquitous to the extent that social and cultural participation increasingly depends on one's ability to make, share and comment on moving-image texts. This participatory definition of literacy arguably has the capacity to encompass all of the other literacies. It does not implicitly valorize one meaning-making system above another, nor does it endorse different, 'special' kinds of literacy. Instead, literacy becomes a question of deciding which are the important meaning-making systems at play in a particular time, place and culture, and how people can develop expressive and communicative capacities within them.

\section{Screening Literacy: Surveying film education in Europe}

In 2012, the European Commission funded a consortium led by the British Film Institute (BFI) to survey and map out the provision and practice of film education across $32 \mathrm{EU}$ and EEA states, to establish a series of 'national profiles' for film education in each country, and to determine whether there were many, or indeed any, strong links and continuities across national boundaries that might together constitute a 'European approach' to film education. The research looked for patterns in the ways film education is organized and funded, the particular settings in which film education is practised, who participates in and who practises film education (and how they are supported) and, perhaps most fundamentally, the rationales for film education followed by organizations and individuals. The sections that follow summarize the answers to each of these questions, while both commenting on common threads of response and picking out some salient national iterations.

\section{Why is film education practised?}

The Screening Literacy researchers asked over 50 respondents across 30 countries for the reasons behind the study of film in their contexts: 20 possible rationales were offered, and respondents were invited to agree with as few or as many as they felt relevant. Those rationales are grouped and summarized in Table 1, with the finding that no single rationale was cited by fewer than eight countries (some variation of 'to promote access to popular cinema', as a rationale in the formal sector, was chosen by around a quarter of respondents). It could be inferred from the data therefore that there are sets of reasons behind the organizing of film education that are shared across 
national boundaries, that there are continuities and common factors shared between school systems ('formal sector' in Table 1), and similarly that there are common rationales within the informal (cultural) sector.

Table 1: Ranking of different rationales for film education in formal and informal settings given by 50 respondents to Screening Literacy (compiled from Reid et al., 2013)

\begin{tabular}{lcc}
\hline Rationale & Formal sector (\%) & Informal (cultural) sector (\%) \\
\hline Textual analysis & 63 & $38^{\star}$ \\
Audience development & 31 & 64 \\
Wider viewing & 51 & 77 \\
Enjoyment & 42 & 74 \\
Heritage - world, European, national & $42-34$ & $61-51$ \\
Popular cinema access / understanding & $22-28$ & $42-48$ \\
\hline
\end{tabular}

* lowest ranked rationale

There are quite salient differences in rationale between the formal and informal education sectors, however. The emphasis on textual analysis in school-based film education across two-thirds of the countries profiled perhaps reflects the common position of film study in mother-tongue language and literature, and the lower ranked rationales for audience development (that is, encouraging different choices in cinemas) and less focus on Europe's film heritage, reflect the reluctance of the school sector to follow external drivers in curriculum practice. The higher ranking for audience development, heritage film and wider viewing in the informal sector all reflect the priorities of the cultural sector, a set of experiences valued in cinema education across much of Europe.

\section{Where does film education actually happen?}

Can we identify a similar set of bifurcations where practice is concerned? Cultural bodies tend to emphasize the importance of visits to the cinema (the various 'national schools film weeks'; the UK's Into Film Festival; the network of Slovenian art house cinemas; a plethora of national cinematheques), and the importance of film festivals, especially those dedicated to children and young people (for example, BUSTER in Denmark, BUFF in Sweden, Giffoni in Italy, Olympia in Greece and Cinekids in the Netherlands). These cultural sector practices share common features across the continent. Indeed, there are a number of supranational organizations that explicitly support film education in these settings: the organization Europa Cinemas offers financial support across Europe and beyond for independent or art house cinemas that screen a proportion of non-native-language European film, and have programmes dedicated to young people both in and outside school. The independent association ECFA (European Children's Film Association) has hundreds of members across Europe, and regularly organizes conferences, training seminars and communication. The cultural film sector in general emphasizes the value of the cinema experience, an experience that is shared, social, spectacular, 'bigger than life' and a means of engaging with world cinema heritage. In this respect, the cultural film sector, which is simultaneously local, national, global and European in its affiliations is distinct from school systems in European countries, which are tied closely to national priorities, curricula and accountability measures. 
While national film archives might be expected also to follow national cultural priorities, one frequently also finds a sense of internationalism to their organization, and a common readiness to engage with film education. For example, Filmoteka Szkolna in Poland circulates DVD box sets of key Polish films to thousands of schools, backed up with a continuing professional development programme for teachers, and a website; the Czech National Film Archive has also created and distributed DVDs of classic Czech animations; the Cineteca di Bologna runs annual exchange and practice forums on archive film; and the Austrian Film Museum has an important education and publishing programme.

\section{How is film education organized - locally, regionally, nationally or transnationally?}

The data submitted to Screening Literacy was organized into three distinct settings for film education: formal education (mandated by national or regional education administrations); cultural spaces (funded and administered by the cultural sector, such as NGOs, cinemas, festivals and archives, and national film agencies); and a 'third space' (Stevenson and Deasy, 2005): in school, but not in the curriculum, such as afterschool film clubs and projects. The responses were then collated into a set of 'country profiles': 30 portraits of film education that could be placed alongside each other to determine patterns of similarity and difference, majoritarian structures and outliers.

The researchers found examples of the close integration of film education functions and structures in Scandinavian countries, with Norway, Denmark and Sweden's Film Institutes having a national remit and a 'national strategy' supported by government. Denmark has a particularly strong interventionist structure whereby 25 per cent of the public funding of film is directed straight to children's film production, distribution, exhibition and education. In the years since this close integration was first mooted in 1997, its Film I Skolen (School Cinema programme) and Film Centralen (online streaming platform for schools) have reached nearly 90 per cent of Danish schools, and a high percentage of the students within them.

Similarly, France follows a dirigiste, centralized approach to film education. Alain Bergala's L'Hypothèse cinéma (2003; English translation, 2016) traces the development of national film education programmes (such as 'Les enfants de cinéma', in which children from every level of schooling are taken to the cinema to see classic films, old and contemporary, chosen by a committee of experts and cineastes) back to the moment of reconstruction after the Second World War, in which concerted attempts were made to mobilize arts and culture to reassert French national identity. It still took a powerful and determined politician, Jack Lang, to mainstream this tendency into the French school system in the 1990s. As a result, by 2016/17, the programmes 'École', 'Collège' and 'Lycée au cinéma' were working with almost 11,000 schools, over 1,300 cinemas and 950,000 students across the school year, representing around 12 per cent of children in France at elementary and high-school level (Les enfants de cinéma, 2018).

In other countries, the relative autonomy of the formal and informal film education sectors is striking, even more so where significant investment is put into each. A core element of film education in the UK is majority funded by delegated National Lottery funding via the Department of Digital Culture, Media and Sport. This is passed on via the lead body for film (the British Film Institute) to a national delivery body, Into Film, which supports roughly a quarter of a million young people with around $f 5$ million per year, most of them in 10,000 after-school film clubs. A separate programme, the BFI Film Academy, reaches around one thousand 16- to 19-year-olds aspiring to work in the film industry every year, and receives roughly $\mathrm{f1}$ million per year from the English 
Ministry of Education. Access to formal film and media study through the four national curricula of the UK, in the form of high-school qualifications for around 150,000 14- to 19-year-olds, is funded directly by the four UK Education ministries via schools in England, Scotland, Wales and Northern Ireland. And, separate again, cinemas around the UK offer programmes for school students and young people outside school. Even though three of these four different sets of activities and programmes - funding for Into Film, the BFI Film Academy and the cinema-schools programme - operate out of the same organization (the BFI), there is little integration of their work.

As cited above, some European nations have deliberately attempted to align or conjoin activity and provision in the formal education sector with that in the cultural sector, by using national strategies for coordinating resources: Northern Ireland offers an example of very close integration, justifying a closer focus.

In common with France and Germany, Northern Ireland can trace the emergence of a fully fledged film-education infrastructure to a post-war reconstruction, this time after the end of the so-called Troubles, which pitched different communities against each from the late 1960s until the Good Friday Agreement of 1998. The devolution of significant governmental powers in the same year led to control of cultural and educational policy, which created the opportunity for a Film Education Policy Working Group to create a strategy for film education in Northern Ireland. The group published its strategy in 2004 as A Wider Literacy (NIFTC/BFI Education Policy Working Group, 2004), mandating a jointly owned film-education strategy, which included the explicit inclusion of film in the school curriculum framework, a formal film qualification for high-school students, creative learning centres for film (and wider subject) training and delivery, a network of after-school film clubs, involvement of the official government education inspectorate (the ETI) in evaluating the effectiveness of the whole programme, and access to heritage and global cinema both online and in cinema venues and film festivals (of which Northern Ireland has three). A sceptic's view of the value of 'strategies' might well be challenged by Northern Ireland as an example of a political-cultural-educational process that combined to create Europe's arguably most robust and integrated film-education infrastructure.

\section{Conclusion: Europe and 'translatable' film culture}

The central conundrum of film education in Europe is a reflection of the tension between European and national identities introduced in the opening section of this paper. How can one reconcile the desire for national determination alongside the political desire to align national cultures under a common European banner? The literary scholar Alexis Nuselovici (2009) offers a potential solution in his conception of 'culture in translation' - a culture that subsists by virtue of continually reassembling, reimagining, recycling and redistributing its stories, myths, ideas and artefacts:

A culture in translation means: a culture which exists not as a transmission of foundational elements, creating lines of tradition, as do the national traditions, but as a permanent translation of elements which, each time, recreate themselves, although keeping some common features (Nuselovici, 2009).

Nuselovici's examples of 'culture in translation' include the accordion (which has metamorphosed in a 500-year-long journey from Germany across the continent) and the cathedral, which similarly has been 'translated' into iterations as different as Scandinavian Lutheran, Scottish Calvinist, Spanish Baroque, and Greek or Eastern 
Orthodox examples. One could also use football, food or, indeed, film - and film education - as examples of 'culture in translation'.

The notion of a 'culture in translation' can help us better understand film education in Europe and the 'to and fro' between nationally determined culture and practice, and broader conceptions of the European. First of all, maybe it can help us avoid the compulsion to seek a too definitive version of film education that we feel ought to apply to every setting, nationality and culture. Film education will unavoidably reflect its cultural hinterland and provenance - whether that is the high aesthetic seriousness of France, the communitarian pragmatism of Northern Ireland, Cyprus, Belgium or other 'divided' cultures, or the cultural and political reconstruction of the post-Berlin-Wall former Soviet Bloc. 'Translatability' might help us out of the cul-de-sac of dogmatic and normative versions of film. After all, the moving image can now be watched on mobile phones, computers, tablets and television screens, all the way up to spectacular IMAX screens. In each presentation, there is an irreducible core of what the moving image is (sound, picture, time), but the screening technology articulates and inflects the image and its reception. Here, there is no 'better' or 'worse' platform, no 'film fetishism' (Buckingham, 2015), and no 'gadgetisme' (Bergala, 2015). We would do well to remember that the fundamental grammar of film arguably did not change after the arrival of sound in 1928, until the almost accidental discovery of 'portrait' format filming made possible by mobile phones.

The question of 'translating' film education from one regional or national location to another, while maintaining a core of common practice, can be better understood through a final example. 'Le cinéma, cent ans de jeunesse' (CCAJ) is a 20+ year-old (and counting) programme of 'watching, making, and thinking film' (La cinémathèque française, n.d.). Over time, CCAJ has built a 'community of practice' (Wenger, 1998) that in 2018 reaches across Europe from France, to Lithuania and Bulgaria in the east, to Portugal and Spain, Italy, Belgium, Germany and the UK, and beyond to Brazil, Cuba and India. Groups of children, aged between 7 and 18, follow a different 'theme' every year, exploring a 'question of cinema' (La cinémathèque française, n.d.). Sample questions include 'why move the camera?', 'the role of the weather in film', the 'long take', or 'foreground/ background'. Participating workshops are offered clips from the world and history of cinema, and a set of exercises that help explore the question, such as shooting one-minute films in the style of the Lumière brothers, or comparing the same action filmed in moving camera single takes and fixed shots. The year culminates in the screening of a set of film essais - eight-minute films shot and edited by children and young people on the year's theme. 'Le cinéma, cent ans de jeunesse' is then 'translated' across nations and continents, age groups, languages and settings (in school, out of school). The programme follows a set of core precepts related to film aesthetics, while incorporating children's experiences and views of the world, and the iterative relationship between watching, making and 'thinking' film. With a little push, the programme can extend to include examples from YouTube, music video and advertising - as it does in the UK version. CCAJ thus offers a vision of transnational cooperation through film that is not subject to jurisdiction, and that is self-regulating, open access, generous and tolerant, while still being coherent and critical. In its way, it offers a model for how Europe might express, celebrate and encompass diversity, culture and history within a kind of communitarian unity. 


\section{Notes on the contributor}

Mark Reid is Head of UK Learning Programmes at the British Film Institute. Since 2012, he has led a number of European research and curriculum projects, including Screening Literacy (2013), the Framework for Film Education (2015) and Film: A Language without Borders (2018).

\section{References}

Bergala, A. (2002) L'Hypothèse Cinéma. Paris: Cahiers du cinéma.

Bergala, A. (2015) 'An avant garde approach'. Online. www.cinematheque.fr/ cinema100ansdejeunesse/en/project/an-educational-adventure.html\#pioneeringA (accessed 20 December 2016).

Bergala, A. (2016) The Cinema Hypothesis: Teaching cinema in the classroom and beyond (FilmmuseumSynemaPublikationen 28). Trans. Whittle, M. Vienna: Austrian Film Museum.

BFI (British Film Institute) (2013) Screening Literacy: Executive summary. Online. http://edition. pagesuite-professional.co.uk//launch.aspx?pbid=25c57922-2908-45b5-b752-e891849e520f (accessed 21 March 2018).

BFI (British Film Institute) (2015) A Framework for Film Education. Online. www.bfi.org.uk/sites/ bfi.org.uk/files/downloads/\%20bfi-a-framework-for-film-education-brochure-2015-06-12.pdf (accessed 21 March 2018).

Buckingham, D. (2003) Media Education: Literacy, learning and contemporary culture. Cambridge: Polity Press.

Buckingham, D. (2015) 'Media education: Where are we going and how can we get there?'. Keynote speech at the Media Meets Literacy Conference, Warsaw, 21-22 May 2015. Online. http://mediameetsliteracy.eu/2015/keynote/ (accessed 2 March 2018).

Burn, A. and Durran, J. (2007) Media Literacy in Schools: Practice, production and progression. London: Paul Chapman Publishing.

La cinémathèque française (n.d.) 'Le Cinéma, cent ans de jeunesse: A cinema education initiative'. Online. www.cinematheque.fr/cinema100ansdejeunesse/en/ (accessed 3 February 2018).

Cope, B. and Kalantzis, M. (eds) (2000) Multiliteracies: Literacy learning and the design of social futures. London: Routledge.

EACEA (Education, Audiovisual and Culture Executive Agency) (2014) 'List of selected projects: Creative Europe - Media'. Online. https://eacea.ec.europa.eu/sites/eacea-site/files/documents/ publication_of_results_audev_2014_en.pdf (accessed 9 March 2018).

EACEA (Education, Audiovisual and Culture Executive Agency) (2016) 'Creative Europe - Film Education 2017 - EACEA/25/2016'. Online. www.up2europe.eu/calls/creative-europe-filmeducation-2017-eacea-25-2016_1476.html (accessed 23 December 2016).

Les enfants de cinéma (2018) 'Les enfants de cinéma: Susciter un désir de cinéma'. Online. http:// enfants-de-cinema.com/ecole-et-cinema/ (accessed 2 March 2018).

Euro Media Literacy (2009) 'The European Charter for Media Literacy'. Online. https:// euromedialiteracy.eu/charter.php?id=3 (accessed 9 March 2018).

European Commission (n.d.) 'Departments and executive agencies'. Online. https://ec.europa.eu/ info/departments_en (accessed 9 March 2018).

European Commission (2018a) 'Media literacy'. Online. https://ec.europa.eu/culture/policy/ audiovisual-policies/literacy_en (accessed 9 March 2018).

European Commission (2018b) 'MEDIA programme (2007-2013)'. Online. https://ec.europa.eu/ programmes/creative-europe/previous-programmes/media_en (accessed 9 March 2018).

Government Digital Service (n.d.) 'Countries in the EU and EEA'. Online. www.gov.uk/eu-eea (accessed 9 March 2018).

Meno Avilys (2015) Anthology of Lithuanian Documentary Cinema [DVD]. Vilnius: Meno Avilys. Contents online. www.menoavilys.org/en/294538/projects/anthology-of-lithuanian-documentarycinema (accessed 2 March 2018).

Messerlin, P., Siwek, S. and Cocq, E. (2004) The Audiovisual Services Sector in the GATS Negotiations. Washington DC: American Enterprise Institute.

NIFTC/BFI Education Policy Working Group (2004) A Wider Literacy: The case for moving image media education in Northern Ireland. Belfast: Northern Ireland Film and Television Commission.

Nuselovici, A. (2009) 'European drift'. Online. www.academia.edu/1721965/European_Drift (accessed 20 December 2016). 
Reid, M., Burn, A., Wall, I. (2013) Screening Literacy. London: BFI.

Roddick, N. (1985) 'If the United States spoke Spanish, we would have a film industry'. In Auty, M. and Roddick, N. (eds) British Cinema Now. London: BFI, 3-18.

School Education Gateway (2017) 'Film literacy: Developing young people's cultural identities and understanding'. Online. www.schooleducationgateway.eu/en/pub/latest/news/film-literacydeveloping-youn.htm (accessed 21 March 2018).

Stevenson, L.M. and Deasy, R.J. (2005) Third Space: When learning matters. Washington, DC: Arts Education Partnership.

Wenger, E. (1998) Communities of Practice: Learning, meaning, and identity. Cambridge: Cambridge University Press. 